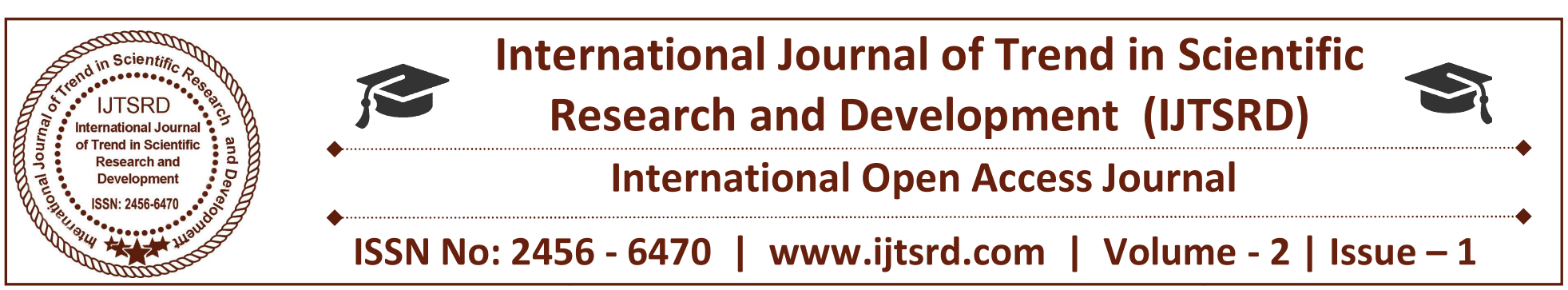

\title{
Studies on Physicochemical Parameters to Assess the Water Quality of Ground Water Sources of Different Places in Daryapur Tahsil, Maharashtra (India)
}

\author{
N. W. Bagalkar \\ Department of Microbiology, Sant Gadge Baba \\ Amravati University, Amravati, India
}

\author{
P. M. Giri \\ Department of Geology, Government Institute of \\ Science Aurangabad, India
}

\begin{abstract}
Groundwater is one of the most valuable natural resources, which supports human health, economic development and ecological variety. Groundwater is a valuable dynamic and replenishes able natural resource in present day and limited in extent. Groundwater resource assessment of a region involves a detailed study of the sub-surface water, including geology and hydrogeology, monitoring and production of well data. The water quality guidelines provide a Limit Value for each parameter for drinking water. It is necessary that the quality of drinking water should be checked at regular time interval, because due to use of contaminated drinking water, human population suffers from varied of water borne diseases. The availability of good quality water is an indispensable feature for preventing diseases and improving quality of life. It is necessary to know details about different physicochemical parameters such as color, taste, odor, TDS, $\mathrm{pH}$, Hardness, Alkalinity, Chlorides, fluoride, Sulphate, Iron, turbidity and Nitrate used for testing of water quality. In present study, Drinking Water Quality, were analysis by various standards and analytical methods and TDS is found in 24 water sample out of 36.
\end{abstract}

Keywords: Drinking Water, Water Quality Parameters, Ground Water

\section{INTRODUCTION}

Water is one of the most important and abundant compounds of the ecosystem. All living organisms on the earth need water for their survival and growth. As of now only earth is the planet having about $70 \%$ surface of earth is covered by water, Majority of water available on the earth is saline in the nature only $3 \%$ of exists as fresh water. Fresh water has become a scare commodity due to over exploitation and pollution [1-2]. But due to increased human population, industrialization, use of fertilizers in the agriculture and man-made activity it is highly polluted with different harmful contaminants. Therefore it is necessary that the quality of drinking water should be checked at regular time interval, because due to use of contaminated drinking water, human population suffers from varied of water borne diseases. It is difficult to understand the biological phenomenon fully because the chemistry of water revels much about the metabolism of the ecosystem and explain the general hydro - biological relationship [3].

Drinking water quality standards describes the quality parameters set for drinking water (Wiki). Ground water is the major sources of drinking water. $65 \%$ of human body made by water, Out of the total water consumed by human beings, more than $50 \%$ of it is consumed for industrial activity and only a small proportion is used for drinking purposes [4]. Industrial development 
(Either new or existing industry expansion) results in the generation of industrial effluents, and if untreated results in water, sediment and soil pollution [5-6]. There are several diseases have been identified among the human beings, which are caused by using contaminated water. Water born disease infections occur during washing, bathing and consumption of contaminated water during food preparations. Therefore it is necessary that the quality of water should be checked at regular time of interval because the financial losses due to water born diseases have negative impact on the nation. Nowadays this is the major problem of developing countries throughout the world. The main aim of the present study was to give an idea about the pollution level of ground water in terms of physicochemical characteristics. There is no information is available in relation to physicochemical characteristics of ground water at Daryapur. Few researchers [7-8-910] in different regions of India have been studied the physico-chemical parameters of the various water bodies. Good Quality of Drinking water is very necessary for improving the life of people and to prevent from diseases [11].

Having mainly excessive amounts of heavy metals such as $\mathrm{Pb}, \mathrm{Cr}$ and $\mathrm{Fe}$, as well as heavy metals from industrial processes are of special concern because they produce water or chronic poisoning in aquatic animals [12]. High levels of pollutants mainly organic matter in river water cause an increase in biological oxygen demand [13], chemical oxygen demand, total dissolved solids, total suspended solids and fecal coli form. They make water unsuitable for drinking, irrigation or any other use [14]. There are trends in developing countries to use sewage effluent as fertilizer has gained much importance as it is considered a source of organic matter and plant nutrients and serves as good fertilizer [15]. Improper waste disposal and over exploitation of resources has affected the quality, not only of tap water, but also of ground water [16]. The recent research in Haryana (India) concluded that it is the high rate of exploration then its recharging, inappropriate dumping of solid and liquid wastes, lack of strict enforcement of law and loose governance are the cause of deterioration of ground water quality [17].
The quality of ground water depends on various chemical constituents and their concentration, which are mostly derived from the geological data of the particular region. Ground water occurs in weathered portion, along the joints and fractures of the rocks [18]. The adverse effects on ground water quality are the results of man's activity at ground surface, unintentionally by agriculture, domestic and industrial effluents [19]. The quality of water may be described according to their physicochemical and microbiological characteristics. Therefore, the quality of ground water varies from place to place, with the depth of water table, and from season to season and is primarily governed by the extent and composition of dissolved solids present in it. However it is very difficult and laborious task for regular monitoring of all the parameters even if adequate manpower and laboratory facilities are available [19-20-21]. Therefore, in recent years an alternative approach based on statistical correlation, has been used to develop mathematical relationship for comparison of physicochemical parameters. The present study deals with study of physico-chemical parameters of ground water in Daryapur City India.

\section{MATERIAL AND METHODS}

\section{Study Area}

The present study was carried out in Drayapur Taluk, Daryapur is a Taluka in Amravati District of Maharashtra State, India. Daryapur Taluka Head Quarters is Daryapur town. It belongs to Vidarbha region. It belongs to Amravati Division. It is located 52 KM towards west from District head quarters Amravati. $601 \mathrm{KM}$ from State capital Mumbai towards west It is too Hot in summer. Daryapur summer highest day temperature is in between $34{ }^{\circ} \mathrm{C}$ to $46{ }^{\circ} \mathrm{C}$. Average temperatures of January is $24{ }^{\circ} \mathrm{C}$, February is $27{ }^{\circ} \mathrm{C}$, March is $31{ }^{\circ} \mathrm{C}$, April is $35^{\circ} \mathrm{C}$, May is $39^{\circ} \mathrm{C}$. ( figure no 1) 


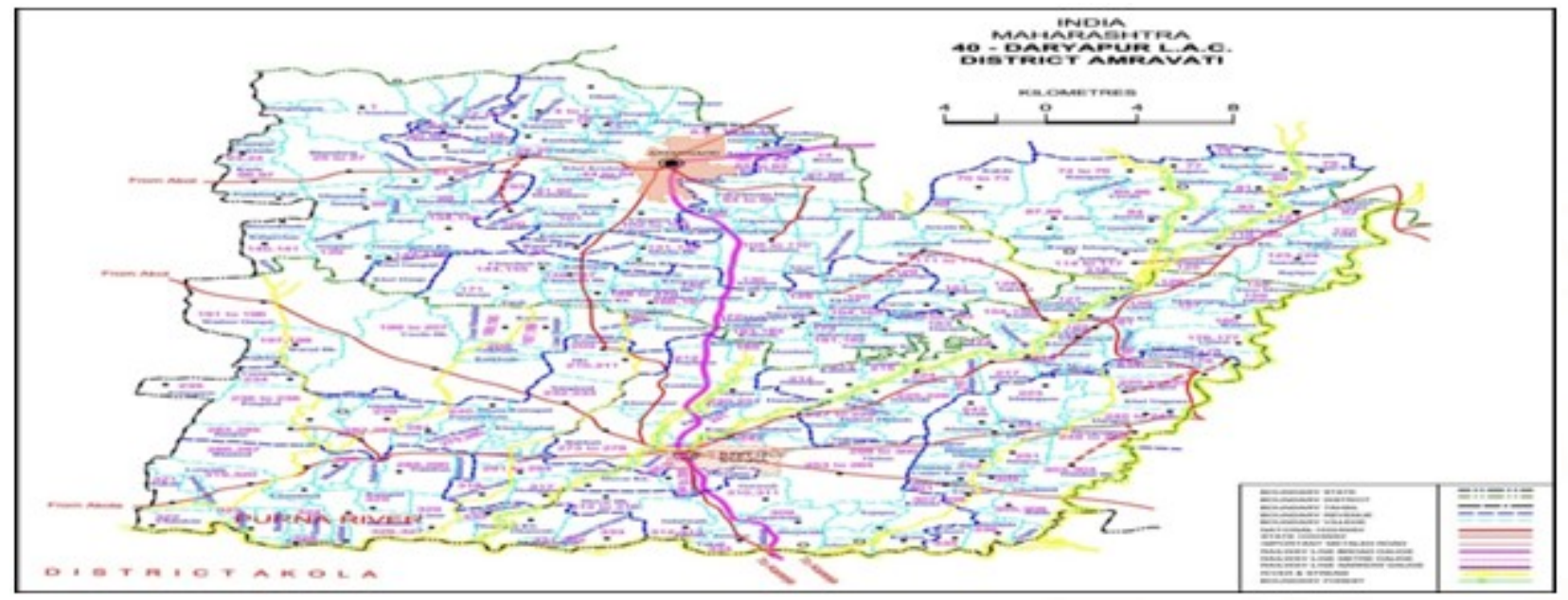

Figure 1: Study Area

The Water Samples from ground water sources were collected from different villages in the morning hours between 10 to 12 am in plastic bottle. The Water samples were immediately brought in to Laboratory for the opinion of various Physico -chemical parameters Such as, TDS, pH, Hardness, Alkalinity, Chlorides, fluoride, Sulphate, Iron, turbidity and Nitrate were estimated in the Laboratory by using Indian Standard Procedures (Titration method, Uv-Visible Spectrophotometer ) [22-23].

\section{Physico-Chemical Properties of Ground Water, Daryapur Tahshil}

It is very essential and important to test the water before it is used for drinking, domestic, agricultural or industrial purpose. Water must be tested with different physico-chemical parameters. Selection of parameters for testing of water is solely depends upon for what purpose we going to use that water and what extent we need its quality and purity. Following different physic chemical parameters are required to for monitoring quality of water.

Odor, color and Test- Color should be transparent in sample. No organic or suspend particle should present. Sample should be odorless. After color and odor test of sample should be acceptable.

Ph- $\mathrm{pH}$ is most important in determining the corrosive nature of water. Lower the $\mathrm{pH}$ value higher is the corrosive nature of water. $\mathrm{pH}$ was positively correlated with electrical conductance and total alkalinity [17]. The reduced rate of photosynthetic action the assimilation of carbon dioxide and bicarbonates which are ultimately responsible for increase in $\mathrm{pH}$, the low oxygen values coincided with high temperature during the summer month. Various factors bring about changes
The $\mathrm{pH}$ of water. The higher $\mathrm{pH}$ values observed suggests that carbon dioxide, carbonate-bicarbonate equilibrium is affected more due to change in physicochemical condition [24] $\mathrm{pH}$ value of water indicates the hydrogen ion concentration in water. The $\mathrm{pH}$ scale is extends from 0 (very acidic) to 14 . As per IS: 105002012 Desirable limit for $\mathrm{pH}$ is 6.5-8.5.

Alkalinity- It is primarily made of carbonate (CO32-) and bicarbonate (HCO3-), alkalinity acts as a stabilizer for $\mathrm{pH}$. Alkalinity, $\mathrm{pH}$ and hardness affect the toxicity of many substances in the water. It is determined by simple dil $\mathrm{HCl}$ titration in presence of phenolphthalein and methyl orange indicators. Acceptable limit of alkalinity is $200 \mathrm{mg} / \mathrm{l}$ and in the absence of alternate water source, alkalinity up to $600 \mathrm{mg} / \mathrm{l}$ is acceptable for drinking.

Total Hardness (TH) - In groundwater hardness is mostly contributed by bicarbonates, carbonates, sulphates and chlorides of calcium and magnesium. So, the principal hardness causing ions are calcium and magnesium. It is measured by titration method by standardised EDTA sol. using Erichrome black T as indicator. [25] Have classified water as soft, moderate, hard and very hard. As per IS: 10500-2012 Desirable limit for TH is 200 and $600 \mathrm{mg} / 1$ in Permissible limit.

Sulphate - Natural water contains sulphate ions and most of these ions are also soluble in water. Many sulphate ions are produce by oxidation process of their ores, they also present in industrial wastes. The way to measure quantity of sulphate is by UV Spectrophotometer. As per IS: 10500-2012 Desirable limit for Sulphate is 200 and $400 \mathrm{mg} / \mathrm{l}$ in Permissible limit 
Chloride -It is measured by titrating a identified volume of sample with standardized silver nitrate solution using potassium chromate solution in water or eosin/fluorescein solution in alcohol as indicator. The latter indicator is an adsorption indicator while the former makes a red colored compound with silver as soon as the chlorides are precipitated from solution. As per IS: $10500-2012$ Desirable limit for fluoride is 250 and $1000 \mathrm{mg} / \mathrm{l}$ in Permissible limit.

Turbidity - Turbidity is a measure of the degree to which the water loses its transparency due to the being there of suspended particulates. It is essential to eliminate the turbidity of water in order to effectively disinfect it for drinking purposes. As per IS: 105002012 Desirable limit for fluoride is 1 and 5 NTU in Permissible limit.

Fluoride - Fluoride occur as fluorspar (fluorite), rock phosphate, triphite, phosphorite crystals etc, in nature. Among factors which control the concentration of fluoride are the climate of the area and the presence of accessory minerals in the rock minerals assemblage through which the ground water is circulating. As per IS: 10500-2012 Desirable limit for fluoride is 1 and 1.5 $\mathrm{mg} / \mathrm{l}$ in Permissible limit.

Nitrate - Nitrate is present in rare water and mainly it is a form of $\mathrm{N} 2$ compound (of its oxidizing state). Nitrate is produced from chemical and fertilizer factories, matters of animals, decline vegetables, domestic and industrial discharge. The method to measure quantity of nitrate is by UV Spectrophotometer. As per IS: 10500-2012 Desirable limit for nitrate is max.45 and no relaxation in permissible limit.

TDS - Water is a good solvent and picks up impurities easily. Pure water is tasteless, colorless, and odorless and is often called the universal solvent. Dissolved solids" refer to any minerals, salts, metals, cations or anions dissolved in water. Total dissolved solids (TDS) include inorganic salts (principally calcium, magnesium, potassium, sodium, bicarbonates, chlorides, and sulfates) and some small amounts of organic matter that are dissolved in water. As per IS: 10500-2012 Desirable limit for TDS is 500 and 2000 $\mathrm{mg} / \mathrm{l}$ in Permissible limit.
Iron- Iron is brought in to the solution and reduced into ferrous state by boiling with $\mathrm{HCl}$ and hydroxylamine hydrochloride. It is then treated with 1-10 phenanthroline at $\mathrm{pH} 3.2$ to 3.3 to form orange red chelate. The color solution obeys beers law. Alter the wavelength to $510 \mathrm{~nm}$ by pressing the nm arrow up or down. As per IS: 10500-2012 Desirable limit for Iron is $0.3 \mathrm{ppm}$.

\section{RESULTS AND DISCUSSION}

The quality of water resources depends on the management of the water sources. This would include anthropogenic discharge as well as the natural physicochemical properties of the area.

The Water Samples from ground water sources were collected from different villages in the morning hours between 10 to $12 \mathrm{am}$ in plastic bottle. Total 36 water sample collected from different villages and different ground water sources such as dug well, hand pump bore well from public sources in Daryapur tahshil. The Water samples were immediately brought in to Laboratory for the Estimation of various Physico chemical parameters Such as, TDS, $\mathrm{pH}$, Hardness, Alkalinity, Chlorides, fluoride, Sulphate, Iron , turbidity and Nitrate were estimated in the Laboratory by using Indian Standard Procedures (Titration method, Uv-Visible Spectrophotometer ) [22-23]. Out of these water sample all parameter near about is on limit except total dissolved solid (TDS), Most of daryapur tahshil containing soil is salinity affected that's why hear present many solid such as mineral springs, carbonate deposits, salt deposits. Out of these 36 water sample 24 sample having TDS is more than 2000 that is (2078, 4035, 3062, 6042, 4074,7 002, 2066, 2037, 3001, 4007, 5002, 2079, 2053, 2064, 2048, 5027, 5002, 2077, 8098, 6009, 4072, 7074, 5005, 15051) and taste of these water sample was salty. Maximum TDS was found in Bhamod village from bower well that is 15051 .

The observed values of physico-chemical parameters of experimental ground water samples are presented in Tables no. 1. 
International Journal of Trend in Scientific Research and Development (IJTSRD) ISSN: 2456-6470

\begin{tabular}{|c|c|c|c|c|c|c|c|c|c|c|c|c|c|c|}
\hline $\begin{array}{l}\text { Name of } \\
\text { Habitation }\end{array}$ & $\begin{array}{l}\text { Type of } \\
\text { Source }\end{array}$ & Tast & Odour & Colour & $\begin{array}{l}\mathrm{Fe} \\
\mathrm{mg} / \\
\mathrm{L}\end{array}$ & $\begin{array}{l}\text { Nitra } \\
\text { te } \\
\mathrm{mg} / \mathrm{L}\end{array}$ & $\begin{array}{l}\mathrm{Fl} \\
\mathrm{mg} / \mathrm{L}\end{array}$ & CL & $\begin{array}{l}\text { TDS } \\
\mathrm{mg} / \mathrm{L}\end{array}$ & $\mathbf{A K}$ & $\begin{array}{l}\text { SULP } \\
\text { HAT } \\
\text { E }\end{array}$ & $\mathrm{pH}$ & $\begin{array}{l}\text { Turbid } \\
\text { ity }\end{array}$ & TH \\
\hline Yeoda & H.P. & Salty & Odourless & Colourless & 0.2 & 19.45 & 0.567 & 195 & 2078 & 169 & 54.87 & 8.2 & 0.84 & 264 \\
\hline Yeoda & D.W. & Salty & Odourless & Colourless & 0.16 & 19.88 & 0.853 & 295 & 4035 & 120 & 42.36 & 8.2 & 0.58 & 314 \\
\hline Yeoda & D.W. & Salty & Odourless & Colourless & 0.27 & 19.66 & 0.849 & 108 & 3062 & 228 & 62.36 & 8.3 & 0.88 & 264 \\
\hline Yeoda & D.W. & Salty & Odourless & Colourless & 0.25 & 20.27 & 0.87 & 247 & 6042 & 124 & 49.34 & 8.3 & 0.92 & 242 \\
\hline Yeoda & D.W. & Salty & Odourless & Colourless & 0.15 & 19.32 & 0.306 & 242 & 4074 & 188 & 74.25 & 8.4 & 0.34 & 208 \\
\hline Yeoda & D.W. & Tastless & Odourless & Colourless & 0.28 & 7.187 & 0.529 & 234 & 1246 & 164 & 53.21 & 8.2 & 0.88 & 274 \\
\hline $\begin{array}{l}\text { VARUD } \\
(\mathrm{KU})\end{array}$ & D.W. & Salty & Odourless & Colourless & 0.38 & 20.29 & 0.84 & 222 & 7002 & 124 & 70.36 & 8.2 & 0.55 & 329 \\
\hline Arala & D.W. & Tastless & Odourless & Colourless & 0.19 & 3.29 & 0.975 & 198 & 950 & 157 & 47.48 & 8.5 & 0.87 & 322 \\
\hline Amla & H.P. & Tastless & Odourless & Colourless & 0.23 & 5.1 & 0.819 & 169 & 1796 & 264 & 38.24 & 8.2 & 0.97 & 208 \\
\hline Amla & H.P. & Tastless & Odourless & Colourless & 0.44 & 6.13 & 0.75 & 242 & 1950 & 192 & 34.25 & 8.2 & 0.83 & 212 \\
\hline Amla & H.P. & Salty & Odourless & Colourless & 0.22 & 18.16 & 0.38 & 279 & 2066 & 298 & 32.21 & 8.3 & 0.97 & 362 \\
\hline Amla & H.P. & Salty & Odourless & Colourless & 0.24 & 28.34 & 0.34 & 216 & 2037 & 186 & 21.75 & 8.3 & 0.76 & 256 \\
\hline Dongargaon & B.W. & Salty & Odourless & Colourless & 0.38 & 29.13 & 0.89 & 236 & 3001 & 175 & 28.33 & 8.4 & 0.69 & 245 \\
\hline Markanda & D.W. & Tastless & Odourless & Colourless & 0.22 & 16.96 & 0.81 & 177 & 1912 & 118 & 22.64 & 7.2 & 0.48 & 174 \\
\hline Nanded & D.W. & Salty & Odourless & Colourless & 0.38 & 21.33 & 0.63 & 249 & 4007 & 138 & 42.33 & 8.2 & 0.55 & 173 \\
\hline Nanded & D.W. & Salty & Odourless & Colourless & 0.41 & 14.23 & 0.78 & 302 & 5002 & 150 & 23.17 & 8.2 & 0.38 & 241 \\
\hline Nanded & H.P. & Salty & Odourless & Colourless & 0.29 & 12.08 & 0.63 & 198 & 2079 & 132 & 46.33 & 8.3 & 0.25 & 262 \\
\hline Nanded & H.P. & Salty & Odourless & Colourless & 0.22 & 28.46 & 0.52 & 128 & 2053 & 167 & 12.64 & 8.4 & 0.91 & 179 \\
\hline Nanded & H.P. & Salty & Odourless & Colourless & 0.38 & 16.23 & 0.47 & 158 & 2064 & 124 & 18.19 & 8.2 & 0.56 & 232 \\
\hline Shinganpur & H.P. & Tastless & Odourless & Colourless & 0.37 & 18.36 & 0.48 & 137 & 1336 & 184 & 29.38 & 7.9 & 0.69 & 178 \\
\hline Gaiwadi & D.W. & Tastless & Odourless & Colourless & 0.32 & 19.34 & 0.62 & 120 & 1724 & 156 & 43.65 & 7.3 & 0.98 & 190 \\
\hline Khairi & H.P. & Salty & Odourless & Colourless & 0.41 & 31.22 & 0.73 & 158 & 2048 & 172 & 88.14 & 7.1 & 0.74 & 188 \\
\hline Khairi & H.P. & Salty & Odourless & Colourless & 0.29 & 18.32 & 0.698 & 160 & 5027 & 234 & 79 & 7.2 & 0.59 & 173 \\
\hline Wander Ga. & Tap & Tastless & Odourless & Colourless & 0.38 & 16.32 & 0.346 & 125 & 734 & 193 & 36.98 & 8.5 & 0.46 & 199 \\
\hline Wander Ga. & D.W. & Salty & Odourless & Colourless & 0.23 & 19.32 & 0.235 & 340 & 5002 & 138 & 54.98 & 7.4 & 0.5 & 196 \\
\hline Wander Ga. & D.W. & Tastless & Odourless & Colourless & 0.38 & 21.33 & 0.145 & 326 & 1253 & 196 & 79.5 & 8.2 & 0.74 & 164 \\
\hline
\end{tabular}


International Journal of Trend in Scientific Research and Development (IJTSRD) ISSN: 2456-6470

\begin{tabular}{|c|c|c|c|c|c|c|c|c|c|c|c|c|c|c|}
\hline Wander Ga. & D.W. & Salty & Odourless & Colourless & 0.42 & 23.12 & 0.214 & 230 & 2077 & 178 & 47.36 & 7.2 & 0.98 & 186 \\
\hline Sanglud & Tap & Tastless & Odourless & Colourless & 0.35 & 18.34 & 0.365 & 237 & 608 & 135 & 48.76 & 8.3 & 0.83 & 182 \\
\hline Sanglud & D.W. & Salty & Odourless & Colourless & 0.37 & 21.34 & 0.248 & 251 & 8098 & 141 & 74.36 & 7 & 0.73 & 144 \\
\hline Sanglud & D.W. & Salty & Odourless & Colourless & 0.23 & 23.45 & 0.654 & 249 & 6009 & 190 & 98.14 & 7.9 & 0.87 & 262 \\
\hline Pimplod & B.W. & Salty & Odourless & Colourless & 0.31 & 28.36 & 0.486 & 242 & 4072 & 136 & 89.47 & 8.2 & 0.84 & 188 \\
\hline Pimplod & D.W. & Salty & Odourless & Colourless & 0.37 & 18.34 & 0.348 & 213 & 7044 & 127 & 80.36 & 8.1 & 1.2 & 154 \\
\hline Jainpur & D.W. & Tastless & Odourless & Colourless & 0.22 & 18.23 & 0.259 & 278 & 756 & 168 & 20.69 & 8.2 & 0.36 & 212 \\
\hline Mahuli & H.P. & Salty & Odourless & Colourless & 0.29 & 12.34 & 0.586 & 198 & 5005 & 164 & 28.64 & 8 & 1.25 & 178 \\
\hline Bhamod & B.W. & Salty & Odourless & Colourless & 0.21 & 22.79 & 0.937 & 124 & 15051 & 146 & 78.45 & 7.4 & 0.15 & 178 \\
\hline Ramtirth & H.P. & Tastless & Odourless & Colourless & 0.42 & 7.947 & 0.887 & 137 & 404 & 154 & 42.36 & 8.1 & 0.33 & 230 \\
\hline
\end{tabular}

\section{Table no. 1}

(TDS: Total Dissolved Solids TH: Total Hardness; AK: Akalinity, Cl: Chloride, Fl: Fluoride)

TDS is positively correlated to $\mathrm{K}$ concentrations of groundwater indicating the influence of agricultural activities and wastewater leakage, where it is known that potassium ion originates from agricultural fertilizer and wastewater [26]. On the other hand, the relationship between $\mathrm{NO}_{3}$ and TDS show similar trend which suggested the leaching of nitrate fertilizers applied in the agricultural areas. $\mathrm{NO}_{3}$ concentration may be further affected by complex hydro chemical processes such as nitrification or denitrification [27-2829-30]. In the given sample fluoride is found in limited quantity but TDS is more than 2000 in most of sample (Table no.1)

\section{CONCLUSION}

In this study, Water quality is dependent on the type of the pollutant added and the nature of mineral found at particular zone of bore well. Monitoring of the water quality of ground water is done by collecting representative water samples and analysis of physicochemical characteristics of water samples at different locations of Daryapur tahshil. In present study was observed Out of 36 water sample 24 sample having TDS is more than 2000. And Daryapur contain salinity affected area hence hear concluded that salinity containing soil having more TDS and these ground water affected sample is not fit for drinking purposes, unfit water are not only devastating to people, but also to animals, fish, and birds also destroy aquatic life. Safe drinking water is vital to sustain life and a satisfactory (adequate, safe and accessible) supply must be available to all.

\section{ACKNOWLEDGEMENT}

The author are sincerely thankful to Dr. S. S. Deshmukh for guided me, the authors are also thankful to all my friends (Roshan Parise, Puran Dhande, Ashish Shende,Nikhilesh Bajaj, Sonali Gawande, Subodh Futane ) for his moral support and suggestions in the preparation of the paper. The author is grateful to the Editor-in-Chief for their encouragement and support.

\section{REFERENCES}

1. Ghose,B.B., and A.K. Basu (1968). Observation on estuarine pollution of the Hooghly by the effluents from a chemical factory complex at Rashasa, west Bengal Env. Health 10 :29-218

2. Gupta,S, and D.N.Shukla (2006) : Physio-Chemical analysis of sewage water and its effect on seed germination and seedling growth of sesamum indicum. J Nat-Ras. Development. 1:5-19.

3. Basavaraja, Simpi, S. M., Hiremath, K. N. S. Murthy, K. N. Chandrashekarappa, Anil N. Patel, E.T.Puttiah, (2011), Analysis of Water Quality Using Physico-Chemical Parameters Hosahalli Tank in Shimoga District, Karnataka, India, Global 
International Journal of Trend in Scientific Research and Development (IJTSRD) ISSN: 2456-6470

Journal of Science Frontier, Research, 1(3), pp 3134

4. Jindal Kumar Manoj, Deshmukh Poonam, Tamrakar Ruchi, Testing and Analysis of Drinking Water Quality of Underground Water located near Rural Area of Risali Chhattisgarh, India, International Research Journal of Environment Sciences, Vol. 3(5), 44-47, May (2014 ).

5. Fakayode, S. O, Onianwa P. C. (2002) Heavy metals contamination of soil and bioaccumulation in Guinea grass (Panicum maximum) around Ikeja Industrial Estate, Lagos, Nigeria. Environ. Geolog, 43: $145-150$.

6. Fakayode, S. O. (2005) Impact assessment of industrial effluent on water quality of the receiving Alaro River in Ibadan, Nigeria. AJEAMRAGEE, 10: 1-13.

7. Kiran BR. 2010. Physico-chemical characteristics of Fish Ponds of Bhadra project at Karnataka, India. Rasayan Journal of Chemistry, 3(4): 671-676

8. Raut KS, Shinde SE, Pathan TS, Sonawane DL. 2011. Seasonal variations in physico-chemical characteristics of Peth Lake at Ambajogai district, BeedMarathwada Region, India. Journal of Research in Biology, 1(4): 258-262

9. Naik TP, Ajayan KV, Lokesh GH. 2012. Physicochemical characteristics of Kunigal Lake in Tumkur district, Karnataka, India. International Journal Chemical Science, 10(2): 655-663

10. Bahekar R, There Y. 2013. Seasonal variation in physico-chemical characteristics of Koradi Lake, district Nagpur, India. Indian Streams Research Journal, 3(2): 1-5

11. Mohamed Hanipha M. and ZahirHussian A., Study of Groundwater Quality at Dindigul Town, Tamilnadu, India, international journal on environmental sciences, 2(1), 68-73, January(2013)

12. Ellis, K.V., (1989), Surface water pollution and its control" Macmillan press Ltd, Hound mill, Basingstoke, Hampshire RG 21 2xs and London, 318, pp 97,100,101 and 208.

13. Kulkarni, G. J., (1997), Water supply and sanitary engineering. 10th Ed. Farooq Kitabs Ghar. Karachi, 497.

14. Hari, O. S., Nepal, M. S. Aryo, and N. Singh. (1994), Combined effect of waste of distillery and sugar mill on seed germination, seeding growth and biomass of okra. Journal of Environmental Biology, 3(15), pp 171-175.

15. Riordan, O', E. G., Dodd, V. A., Tunney, H., Fleming, G. A, (1983), The chemical composition of sewage sludges, Ireland Journal of Agriculture Research, 25, 239-49.

16. Varsha Nigam, Neelam Behl, M.C. Kanchan. 2013 In physico-chemical parameters for testing of water- a review.

17. Gupta, D. P., Sunita and J. P. Saharan, (2009), Physiochemical Analysis of Ground Water of Selected Area of Kaithal City (Haryana) India, Researcher, 1(2), pp 1-5.

18. APHA, Standard methods for analysis of water and wastewater.18thEd. American Public Health As sociation,Inc., Washington D C. 1992.

19. Jena V.K., Gupta S. and Dixit S., 2012. Physicochemical parameters assessment of ground water in different sites of Bhilai city, Chhattisgarh Rasayan J. Chem., 5:506-509.

20. Mintz E., Bartram J., Lochery P. and Wegelin M., 2001. Not just a drop in the bucket: expanding access to point-of-use water treatment systems. American Journal of Public Health, 91(10): 15651570.

21. Wuta M., Nyamadzawo G., Mlambo J. and Nyamugafat P., 2016. Ground and surface water quality along a dambo transect in Chihota smallholder farming area, Marondera district, Zimbabwe, Physics and Chemistry of the Earth, 92:112- 118

22. Trivedy RK, Goel PK. Chemical and biological methods for water pollution studies, Environmental Publication, Karad, Maharashtra, 1986.

23. APHA. Standard Methods for Examination of Water and Wastewater, 20th Edition, American Public Health Association, Washington D. C. 1985.

24. Karanth, K.R (1987): Groundwater Assessment Development and Management Tata McGraw Hill publishing company Ltd., New Delhi, 725p.

25. Durfor, C.N. and Becker, E., (1964) "Public water supplies of the 100 largest cities in the United States", In Geological Survey Water Supply, U.S. Government Printing Office, Washington, Paper No. 1812, pp. 364.

26. Trauth and Xanthopoulos, 1997 R. Trauth, C. Xanthopoulos Nonpoint pollution of 
International Journal of Trend in Scientific Research and Development (IJTSRD) ISSN: 2456-6470

groundwater in urban areas Water Res., 31 (1997), pp. $2711-2718$

27. Arnade, 1999 L.J. Arnade Seasonal correlation of well contamination and septic tank distance Ground Water, 37 (1999), pp. 920-923

28. Graniel et al., $1999 \quad$ C. E. Graniel, L.B. Morris, J.J. Carrillo-Rivera Effects of urbanization on groundwater resources of Merida, Yucatan, Mexico Environ. Geol., 37 (1999), pp. 303-312
29. Rosen et

al., 1999 M.R. Rosen, J. Bright, P. Carran, M.K. Stewart, R. Reeves Estimating rainfall recharge and soil water residence times in Pukekohe, New Zealand, by combining geophysical, chemical, and isotopic methods Ground Water, 37 (1999), pp. 836-844

30. Sliva and Williams, 2001 L. Sliva, D.D. Williams Buffer area versus whole catchment approaches to studying land-use impact on river water quality Water Res., 35 (2001), pp. 3462-3472 